\title{
Immediate Effects of Moving Myofascial Decompression Therapy for Young Adults with Nonspecific Neck Pain
}

\author{
Kayoon Min ${ }^{a}$, Namwoo Kim ${ }^{a}$, Yongwoo Lee ${ }^{a}(\sqrt{1}$ \\ aDepartment of Physical Therapy, College of Health and Welfare, Sahmyook University, Republic of Korea
}

Objective: The purpose of this study was to investigate the effects of myofascial decompressiontherapy using moving suction on body temperature, pain, neck disability index, and cervical rotation for young adult with nonspecific neck pain.

Design: Two-group pretest-posttest design.

Methods: The subjects were randomly assigned 22 patients with chronic cervical pain who met the study conditions to the experimental group $(n=11)$ and the control group $(n=11)$. In the experimental group, the myofascial decompressiontherapy (MDT) was performed for 10 minutes using moving suction withnegative $15 \mathrm{mmHg}$ pressure from the insertion to the origin of the upper trapezius muscle, while the control group without negative pressure. In order to investigate the effects of the intervention, an infrared thermometer, a visual analogue scale, neck disability index, and goniometer were used.

Results: As a result of comparing the pre- and post- changes in each group according to the intervention, skin temperature, pain, neck disability index, and cervical rotation in both the experimental and control groups were significantly improved ( $\mathrm{p}<0.05)$. Comparison of pre- and post- changes between the experimental and control groups showed significant differences for pain and cervical rotation $(\mathrm{p}<0.05)$, but no significant difference was found in the body temperature and neck disability index.

Conclusions: Based on the results, MDT using moving suction was effective in reducing pain and increasing of cervical rotation for young adult with nonspecific neck pain.

Key Words: Neck pain, Myofascial pain syndrome, Upper trapezius, Chronic pain

\begin{abstract}
서론
목 통증은 흔하게 발생하는 질환으로 $70 \%$ 의 개인이 일 생 중 어느 시점에 영향을 받으며 이들 중 약 5 10\%가 목 장애를 겪고 있다[1]. 목 주변 구조물은 퇴행성 질환, 외상 또는 염증성 질환 등 특정 원인에 의해 영향을 받을 수 있으며 이로 인해 목 통증이 발생할 수 있으며[2], 그 이외에도 습관적 자세 등 특정 질환과 관련없이 통증이 발생할 수 있으며 기계적 장애가 있는 경우를 비특이적 목 통증이라고 한다[3]. 목 통증이 발생하는 원인은 여러 가지가 있지만 그 중에 한 가지가 일상생활에서 좋지 않 은 자세를 장시간 유지함에 따라 생기는 목과 어깨 근육 의 불균형으로 인한 어깨부위의 근막 긴장이다[4]. 이로 인한 연부조직의 손상에 의한 통증은 $87.5 \%$ 에 해당되며,
\end{abstract}

사고로 인한 충격으로 발생하는 통증이 $5.3 \%$, 그 외 기타 원인에 의한 통증이 $4.5 \%$ 를 차지한다[5]. 목과 어깨의 불 균형이 발생하면 연부조직이 과사용되고 이는 만성목통증 을 일으키는 원인이 된다. 이러한 과사용은 위등세모근의 과도한 긴장을 초래한다고 하였다. 위등세모근은 해부학 적으로 목과 어깨에 위치하였으며, 한쪽이 수축하게 되면 머리와 목을 측면굴곡과 회전을 시키고 얼굴은 반대방향 으로 회전하는 움직임이 일어나게 된다[6]. 이러한 이유로 위등세모근의 문제는 목의 움직임을 제한할 수 있다. 또 한 위등세모근은 서있거나, 앉아있을 때 중력에 대항하는 근육으로써, 머리의 위치를 안정시켜야 하기 때문에 항상 긴장해야 하는 긴장성 근육이다[7]. 만약 위등세모근의 문 제를 해결하지 않는다면, 위등세모근의 과긴장 상태가 계 속 유지되어 목통증, 목 기능 장애 그리고 위등세모근 섬

Received: May 14, 2021 Revised: May 27, 2021 Accepted: May 27, 2021

Corresponding author: Yongwoo Lee (ORCID https://orcid.org/0000-0001-9978-1924)

Department of Physical Therapy, Sahmyook University

815, Hwarang-ro, Nowon-gu, Seoul, Republic of Korea [01795]

Tel: + 82-2-3399-1636 Fax: + 82-2-3399-1639 E-mail: yongwo2@syu.ac.kr

This is an Open-Access article distributed under the terms of the Creative Commons Attribution Non-Commercial License (http://creativecommons.org/licenses/ by-nc/4.0) which permits unrestricted non-commercial use, distribution, and reproduction in any medium, provided the original work is properly cited.

Copyright @ 2021 Korean Academy of Physical Therapy Rehabilitation Science 
유 내 부위에 통증유발점을 형성하게 된다 $[8,9]$.

이를 종합해 볼 때 위등세모근 치료는 목통증을 해결하 기 위한 필수 요소이며, 이를 위한 치료법으로 허혈성압 박법, 능동이완기법(Active Release Technique; ART) 등 여러 형태의 근막이완요법이 소개되었다[10]. 이러한 여러 근막이완요법 중 근막감압치료(myofascial decompression therapy; $\mathrm{MDT}$ )는 치료부위에 음압을 가하여 근막을 이 완시켜주는 기법으로 대체 의학 치료 방법의 한 유형으 로 많이 사용되어 왔다 $[11,12]$. $\mathrm{MDT}$ 는 근골격계질환뿐 아니라 류마티스 질환, 심혈관 질환, 피부 질환, 염증성 질환, 신경 정신병 문제 등 여러 급성, 만성 질환의 치료 에 적용되어 왔다 $[13,14]$. 다양한 선행 연구에서 $\mathrm{MDT}$ 가 근골격계 질환 치료에서 통증에 효과가 있음이 나타 났다[14-16]. 또한 적용 부위의 혈액 순환을 증가시켜 근 육 이완을 증가시키고 회복을 앞당긴다는 연구 결과가 있다[17, 18]. 그러나, MDT에 대한 선행연구 중 대부분 이 감압을 가하기 위해 부황 등의 장비를 이용해 고정된 지점에만 적용하였다. 본 연구와 같이 감압을 가하며 근 육을 따라 움직이면서 치료효과를 본 연구는 부족한 실 정이다. 따라서, 본 연구에서는 목통증을 겪고 있는 일반 인을 대상으로 $\mathrm{MDT}$ 를 위등세모근을 따라 움직이면서 적용했을 때 목의 통증과 더불어 목장애지수, 목의 회전 범위, 위등세모근 주변의 피부온도에 미치는 효과를 보 고자 하였다.

\section{연구방법}

\section{연구대상}

본 연구의 대상자들은S대학에 재학 중인 학생 중 평소 목 통증을 호소하는 젊은 성인을 대상으로 교내 게시판에 2주간 포스터를 붙여 모집하였다. 선정기준으로는, 목기능 장애지수(Neck Disability Index; NDI)가 5점 이상인 자, 목 통증이 3 개월 이상 지속된 자로 정하였다. 제외 기준 은 3 개월 이내에 목과 어깨에 수술 경력이 있는 자, 섬유 근육통이 있는 자, 이전에 스테로이드 주사 혹은 침 치료 를 받은 자, 목뼈골절, 디스크 탈출 등 특정 질환을 않고 있는 자로 하였다[19]. 모든 대상자들에게 실험 목적을 설 명한 후 동의서를 받았으며 실험도중 언제든지 실험의 동 의를 철회할 수 있다고 하였다.

\section{연구절차}

본 연구는 실험군-대조군의 사전-사후검사 설계이다. 고 주파 자극기(HR-S580, HR Meditech, Korea)를 이용하여 10 분 동안 $\mathrm{MDT}$ 를 적용하는 실험군과 10 분 동안 $\mathrm{MDT}$ 를 적용하지 않고 눈 가림법을 적용한 대조군으로 구분하

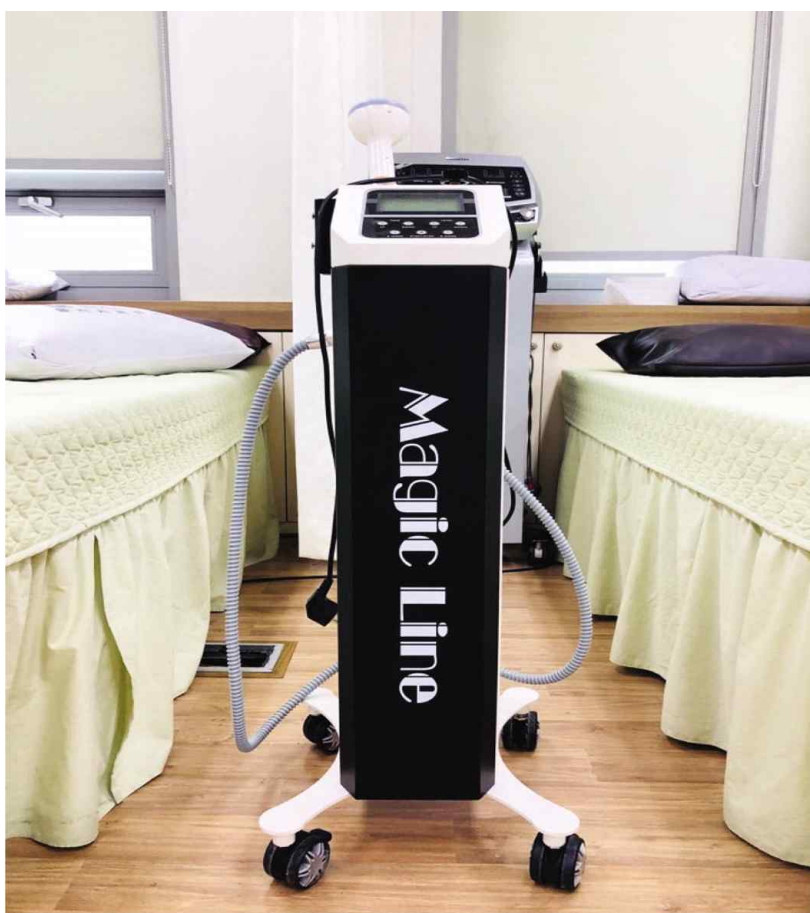

Figure 1. Decompression Applicator

여 진행하였다(Figure 1). 대상자의 무작위화를 위하여 난 수표를 이용하여 모두 배치될 때까지 교대로 집단1(실험 군)과 집단2(대조군)로 배정하였다.

\section{중재 방법}

$\mathrm{MDT}$ 를 적용하기 위해 고주파 자극기의 석션 기능(음압 형성)을 사용하였다. 두 군 모두 고주파 기능은 제거하고 실험군은 $15 \mathrm{mmHg}$ 의 압력으로 음압을 설정하였고 대조 군은 $0 \mathrm{mmHg}$ 의 압력으로 설정하였다. $\mathrm{MDT}$ 적용을 위 해 대상자는 엎드린 자세에서 고주파 자극기의 헤드 부분 을 위등세모근의 기시점(Occipital bone)부터 정지점 (Acromion)까지 왕복하여 이동하면서 10 분간 MDT치료 를 적용하였다(Figure 2).

\section{측정방법 및 도구}

\section{통증}

대상자의 통증 정도를 알아보기 위해 시각통증척도를 이용하였다.VAS는 통증을 측정하는 주관적인 평가도구 로 0 부터 10 까지 통증의 정도를 나타낸다. 통증에 대한 증상이 없는 0 , 참기 힘들 정도로 매우 심한 통증이 있는 상태를 10 으로 정하여 대상자가 현재 본인의 통증을 표시 하도록 한다. 이 평가도구의 급내 상관 계수(Intraclass Correlation Coefficients; ICC)는 0.9로 높은 신뢰도를 갖는다[20]. 


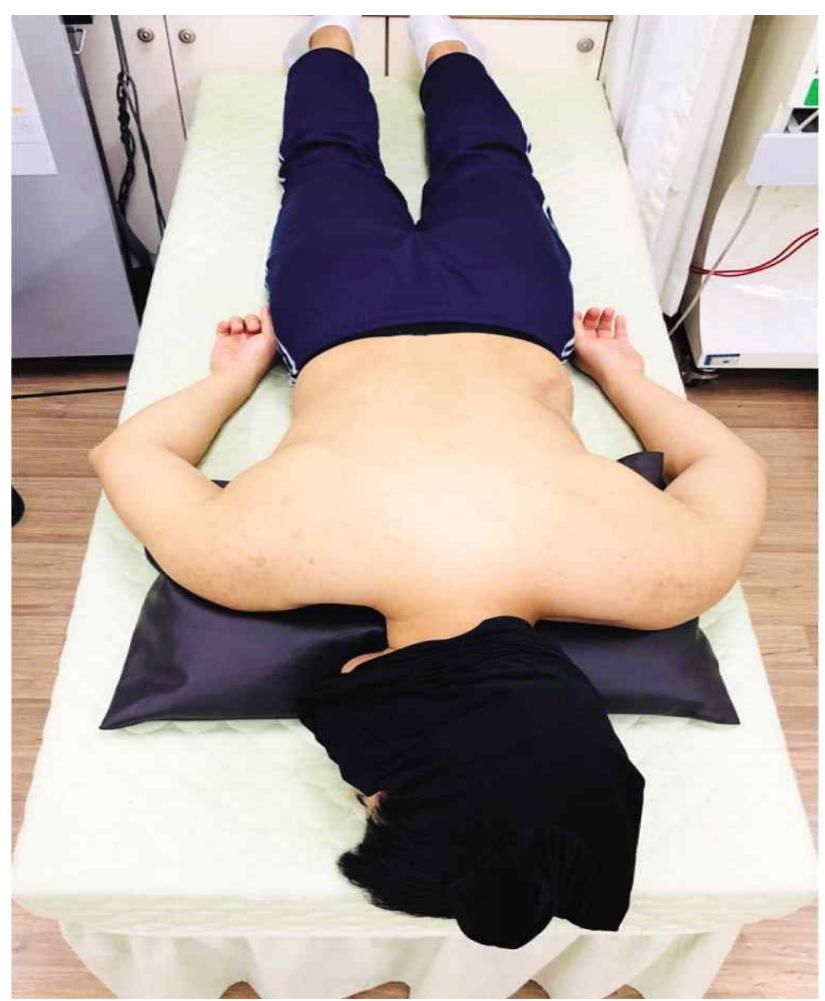

Figure 2. Participant's position

\section{피부 온도}

피부 온도 변화의 오차를 줄이기 위해 대상자를 실험 30 분전 도착하게 하였으며 실험실 온도를 일정하게 유지 하였다. 실험 전 침대에 엎드려 위등세모근을 이완한 상 태로 어깨뼈봉우리로부터 내측으로 $4 \mathrm{~cm}$ 떨어진 부분에 서 적외선 온도계를 이용해 피부온도를 측정하였다(Figure 3).

\section{목기능장애자수}

목기능장애지수는 목기능을 측정하는 도구로, $0 \sim 4$ 점 은 장애 없음(no disability), 5 14점은 경도 장애(mild disability), 15 24점은 중등도 장애(moderate disability), 25 34점은 중증 장애(severe disability), 35점 이상은 완 전 장애(complete disability)로 분류하였다[21].이 평가도 구의 급내 상관 계수는 0.93 으로 높은 신뢰도를 갖는다 [22].

\section{목의 회전 범위}

목의 회전 범위를 측정하기 위해 고니오메터를 사용하 였다. 대상자는 등받이가 있는 의자에 양쪽 어깨가 수평이 되도록 앉았다. 고니오메터의 축은 정수리의 중앙에 두었 고, 고정자는 대상자의 어깨뼈 봉우리에 수평하도록, 가동

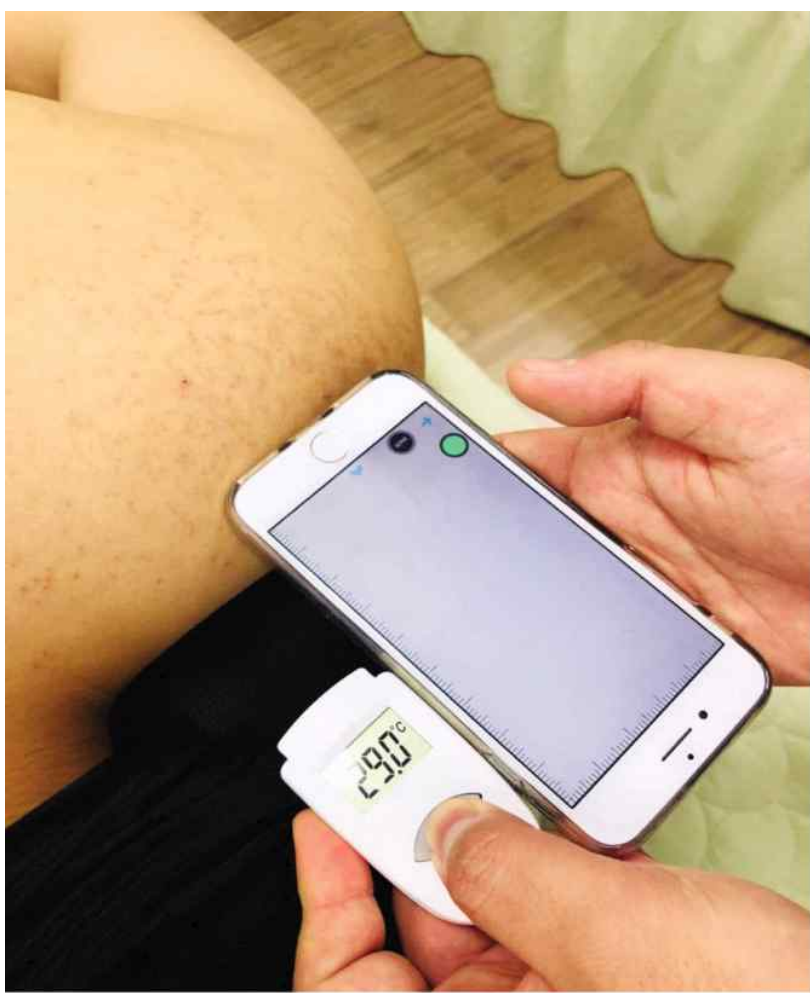

Figure 3. Measurement of skin temperature

자는 대상자의 코에 수평하도록 배치하였다. 대상자가 목 을 회전했을 때의 각도를 측정하였고, 오른쪽과 왼쪽을 모 두 측정하여 범위가 더 제한적인 쪽의 각도를 기록하였다. 고니오메터의 검사자내 신뢰도 $(\mathrm{ICC}=0.84 \sim 0.96)$ 와 검사 자간 신뢰도( $\mathrm{ICC}=0.72 \sim 0.94)$ 가 높은 수준으로 나타났다 [23].

\section{자료 분석}

본 연구의 모든 자료의 통계분석은 SPSS(ver. 19, IBM Co., USA)를 이용하였다. 자료는 Shapiro-Wilk 검정에 의한 정규성 검정을 하였고, 평균과 표준편차를 산출하였 다. 정규성 검정 후 정규분포 가정을 만족하여 대상자의 인구 사회학적 특성은 실수와 백분율, 평균과 표준편차로 분석하였으며, 군간 동질성 검정을 위해 독립표본 $\mathrm{t}$ 검정 과 카이제곱 검정을 사용하였다. 중재 전·후 종속변수의 변화는 대응표본 $\mathrm{t}$ 검정으로 분석하였으며, 군간 효과를 비교하기 위해 독립표본 $\mathrm{t}$ 검정을 사용하였다. 자료의 모 든 통계적 유의수준은 $\alpha=0.05$ 로 설정하였다.

\section{연구결과}

본 연구에 참여한 실험군 11 명과 대조군 11 명의 일반적 특성은 제시된 표와 같으며, 성별, 나이, 키, 몸무게 등 모 
Table 1. General Characteristics of Participants

\begin{tabular}{|c|c|c|c|c|}
\hline \multirow{2}{*}{ Characteristics } & \multicolumn{2}{|l|}{ Mean (SD) } & \multirow{2}{*}{$\chi^{2} / \mathbf{t}$} & \multirow{2}{*}{$\mathbf{p}$} \\
\hline & Experimental group $(n=11)$ & ControlGroup $(n=11)$ & & \\
\hline Sex (male/female) & $7 / 4$ & $4 / 7$ & 1.250 & 0.211 \\
\hline Age (years) & $22.81(1.99)$ & $21.63(2.14)$ & 1.340 & 0.180 \\
\hline Height (cm) & $172.90(10.26)$ & $170.18(9.62)$ & 0.461 & 0.645 \\
\hline Weight (kg) & $67.09(18.76)$ & $64.63(14.72)$ & 0.263 & 0.793 \\
\hline
\end{tabular}

The values are presented mean (SD)

NDI: neck disability index, VAS: visual analogue scale, ST: skin temperature

두 동질함을 확인할 수 있었다(Table 1).

\section{목기능장애지수의 전. 후 변화}

실험군, 대조군의 목기능장애지수 전·후 변화는 표와 같다(table 2, table 3). 실험군은 실험 전 10.72 \pm 3.38 점에 서 실험 후 8.09 \pm 4.32 점으로 유의하게 감소하였고, 대조 군은 실험 전 9.72 \pm 3.44 점에서 실험 후 $8.36 \pm 3.56$ 점으로 유의하게 감소했다. 실험군과 대조군 간 변화의 차이는 실험군 $2.63 \pm 2.69$ 점, 대조군 $1.36 \pm 2.01$ 점으로 통계적으로 유의한 차이가 나타나지 않았다(table 4).

\section{목병ㅎㅎㅈ전의 전·후 변화}

실험군, 대조군의 $\mathrm{ROM}$ 전·후 변화는 표와 같다(table 2 , table 3 ). 실험군은 실험 전 $50.26 \pm 4.83^{\circ}$ 에서 실험 후 $64.70 \pm 8.96^{\circ}$ 으로 유의하게 감소하였고, 대조군은 실험 전 $52.62 \pm 8.10^{\circ}$ 에서 실험 후 $57.62 \pm 9.57^{\circ}$ 으로 유의하게 감 소했다 $(\mathrm{p}<0.05)$. 실험군과 대조군 간 변화끼리 차이는 실 험군 $14.45 \pm 9.45^{\circ}$, 대조군 $4.99 \pm 5.11^{\circ}$ 으로 통계적으로 유
의한 차이가 나타났다 $(\mathrm{p}<0.05)$. 그룹 간 효과를 비교하기 위하여 사후검정을 실시한 결과 실험군이 대조군보다 통 계적으로 더 유의한 것으로 나타났다 $(\mathrm{p}<0.05)(\mathrm{table} 4)$.

\section{통증의 전·후 변화}

실험군, 대조군의 $\mathrm{VAS}$ 전·후 변화는 표와 같다(table 2, table 3). 실험군은 실험 전 4.36 \pm 1.62 에서 실험 후 $2.18 \pm 2.01$ 로 유의하게 감소하였고, 대조군은 실험 전 $4.73 \pm 1.35$ 에서 실험 후 $3.82 \pm 1.33$ 으로 유의하게 감소했다. 실험군과 대조 군 간 변화 차이는 실험군 $2.18 \pm 0.87$, 대조군 $0.91 \pm 0.54$ 로 통계적으로 유의한 차이가 나타났다 $(\mathrm{p}<0.05)$. 그룹 간 효과를 비교하기 위하여 사후검정을 실시한 결과 실험군 이 대조군보다 통계적으로 더 유의한 것으로 나타났다 $(\mathrm{p}$ $<0.05)($ table 4$)$

\section{피부온도의 전·후 변화}

실험군과 대조군의 피부온도 전·후 변화는 표와 같다

Table 2. Changes of NDI, Rotation of neck, VAS, ST for experimental group

$(\mathrm{n}=11)$

\begin{tabular}{|c|c|c|c|c|}
\hline & \multirow{2}{*}{$\begin{array}{l}\text { Pre } \\
\text { Post }\end{array}$} & \multirow{2}{*}{$\begin{array}{l}\text { Mean (SD) } \\
\text { Experimental group }(n=11)\end{array}$} & \multirow{2}{*}{$\mathbf{t}$} & \multirow{2}{*}{$\mathbf{p}$} \\
\hline & & & & \\
\hline \multirow{2}{*}{ NDI (Score) } & Pre & $10.72(3.38)$ & \multirow{2}{*}{2.669} & \multirow{2}{*}{0.008} \\
\hline & Post & $8.09(4.32)$ & & \\
\hline \multirow{2}{*}{ Rotation of neck $\left(^{\circ}\right)$} & Pre & $50.26(4.83)$ & \multirow{2}{*}{2.934} & \multirow{2}{*}{0.003} \\
\hline & Post & $64.70(8.96)$ & & \\
\hline \multirow{2}{*}{ VAS (mm) } & Pre & $4.36(1.62)$ & \multirow{2}{*}{2.976} & \multirow{2}{*}{0.003} \\
\hline & Post & $2.18(2.01)$ & & \\
\hline \multirow{2}{*}{$\mathrm{ST}\left({ }^{\circ} \mathrm{C}\right)$} & Pre & $32.12(1.45)$ & \multirow{2}{*}{2.940} & \multirow{2}{*}{0.003} \\
\hline & Post & $33.45(1.12)$ & & \\
\hline
\end{tabular}

The values are presented mean (SD)

NDI: neck disability index, VAS: visual analogue scale, ST: skin temperature 
Table 3. Changes of NDI, Rotation of neck, VAS, ST for control group

$(\mathrm{n}=11)$

\begin{tabular}{|c|c|c|c|c|}
\hline & \multirow{2}{*}{$\begin{array}{l}\text { Pre } \\
\text { Post }\end{array}$} & Mean (SD) & \multirow{2}{*}{$\mathbf{t}$} & \multirow{2}{*}{$\mathbf{p}$} \\
\hline & & Control group $(n=11)$ & & \\
\hline \multirow{2}{*}{ NDI (Score) } & Pre & $9.72(3.44)$ & \multirow{2}{*}{2.050} & \multirow{2}{*}{0.040} \\
\hline & Post & $8.36(3.56)$ & & \\
\hline \multirow{2}{*}{ Rotation of neck $\left({ }^{\circ}\right)$} & Pre & $52.62(8.10)$ & \multirow{2}{*}{2.756} & \multirow{2}{*}{0.006} \\
\hline & Post & $57.62(9.57)$ & & \\
\hline \multirow{2}{*}{ VAS (mm) } & Pre & $4.73(1.35)$ & \multirow{2}{*}{2.887} & \multirow{2}{*}{0.004} \\
\hline & Post & $3.82(1.33)$ & & \\
\hline \multirow{2}{*}{$\mathrm{ST}\left({ }^{\circ} \mathrm{C}\right)$} & Pre & $31.66(1.16)$ & \multirow{2}{*}{2.360} & \multirow{2}{*}{0.180} \\
\hline & Post & $32.58(1.18)$ & & \\
\hline
\end{tabular}

The values are presented mean (SD)

NDI: neck disability index, VAS: visual analogue scale, ST: skin temperature

Table 4. Difference comparison of NDI, Rotation of neck, VAS, ST between experimental and control group

$(n=22)$

\begin{tabular}{|c|c|c|c|c|}
\hline & \multicolumn{2}{|l|}{ mean $(\mathrm{SD})$} & \multirow{2}{*}{$\mathbf{t}$} & \multirow{2}{*}{$\mathbf{p}$} \\
\hline & Experimental group $(\mathrm{n}=11)$ & Control group $(n=11)$ & & \\
\hline NDI (Score) & $-2.64(2.57)$ & $-1.36(1.92)$ & 1.338 & 0.181 \\
\hline Rotation of neck $\left(^{\circ}\right)$ & $14.45(9.01)$ & $4.99(4.87)$ & 3.053 & 0.002 \\
\hline VAS (mm) & $-2.18(0.83)$ & $-0.91(0.51)$ & 3.119 & 0.002 \\
\hline $\mathrm{ST}\left({ }^{\circ} \mathrm{C}\right)$ & $1.33(1.08)$ & $0.93(0.96)$ & 0.658 & 0.511 \\
\hline
\end{tabular}

The values are presented mean (SD)

NDI: neck disability index, VAS: visual analogue scale, ST: skin temperature

(table 2, table 3). 실험군은 실험 전 $32.12 \pm 1.45{ }^{\circ} \mathrm{C}$ 에서 실험 후 $33.45 \pm 1.12{ }^{\circ} \mathrm{C}$ 으로 유의하게 증가하였고, 대조군 은 실험 전 $31.66 \pm 1.16{ }^{\circ} \mathrm{C}$ 에서 실험 후 $32.58 \pm 1.18{ }^{\circ} \mathrm{C}$ 으 로 유의하게 증가했다. 실험군과 대조군 간 변화끼리 차 이는 실험군 $1.33 \pm 1.07{ }^{\circ} \mathrm{C}$, 대조군 $0.93 \pm 1.01{ }^{\circ} \mathrm{C}$ 으로 통 계적으로 유의한 차이가 나타나지 않았다 $(\mathrm{p}>0.05)(\mathrm{table}$ 4).

\section{고찰}

본 연구는 근육을 따라 이동하면서 $\mathrm{MDT}$ 를 적용한 근 막이완술이 목통증을 가진 젊은 성인의 목 회전 범위, 목 기능장애 지수, 통증 및 피부 온도 변화를 측정하고 두 그 룹 간 차이를 비교하고자 시행하였다.

목통증의 다양한 원인 중에서 기계적인 장애가 가장 흔 한 원인이며[24], 그 중에서 연부조직의 긴장이 기계적인 장애를 일으킬 수 있다는 것은 많은 연구를 통해 밝혀졌 다[4]. 이런 연부조직 긴장을 해결하기 위해 스트레칭, 근
력강화 운동, 연부조직 가동술, 근막이완술 등 여러 가지 방법이 사용되고 있다[25, 26]. 특히, MDT는 대체 의학 의 한 분야로 여러 세기 동안 통증 완화를 위해 사용되어 져 왔다 $[12,27]$. 근골격계 질환뿐 아니라, 심혈관계, 피 부, 염증, 호흡기계 등 다양한 만성 질환을 치료하는데 적 용되었다[14, 28, 29].

본 연구에서는 실험군에게는 음압이 발생하는 장비의 해드를 이용하여 위등세모근의 기시부와 정지부를 따라 이동하며 10 분 동안 $\mathrm{MDT}$ 를 적용하였으며, 대조군에게는 음압을 적용하지 않고 같은 부위를 10 분 동안 해드를 이동 하였다. 중재 직후 측정한 결과에서 NDI 점수, 목뼈 회전 범위, VAS, 피부온도가 실험군과 대조군에서 모두 유의 하게 증가하였다 $(\mathrm{p}<0.05)$. 그렇지만 군간 차이에서는 목뼈 회전 범위와 $\mathrm{VAS}$ 에서만 유의한 차이를 나타냈다 $(\mathrm{p}<0.05)$.

$\mathrm{MDT}$ 의 통증 조절과 관련한 생리학적인 작용원리는 확실히 밝혀지지 않았지만, 다음의 몇 가지로 요약할 수 있다. 첫번째로 지압이나 침과 같이 세로토닌, 엔도르핀, 코티솔과 같은 통증을 차단할 수 있는 화학전달물질을 방 
출하여 궁극적으로 통증을 완화할 수 있는 요소로 작용한 다[30]. 둘째로, 통각 수용 활성화는 만성 통증에 기여하 고 MDT가 항 통각 효과와 역자극(counterirritation)을 통 해 통증을 감소시킨다는 것이다 $[31,32]$. 셋째로, 위약효 과에 의한 것이다. 최근 무작위 연구에서 모의장치(sham device)가 위약(placebo pill)보다 통증 완화에 더 효과적 이라는 보고가 있었다[33]. 이외에도, Tham 등[27]에 의 하면 MDT 치료 시음압이 발생하여 적용 부위의 피부와 깊은 근막 사이에 존재하는 표면 근막의 움직임을 원활하 게 만들고 근육의 움직임을 효과적으로 만들 수 있게 하 고 이는 연부조직의 장력을 제거하고 조직을 복원하여 물 리적인 결함을 완화시킬 수 있다고 하였다.

MDT를 적용하는 방법에도 차이가 있을 수 있는데, 본 연구에서는 근막이완을 좀 더 효과적으로 하고자 음압 발 생 장비를 이용하여 위등세모근의 기시부와 정지부를 따 라 이동하면서 $\mathrm{MDT}$ 를 적용하였다. 다른 선행 연구들에 서는 전통적인 석션(cupping) 컵을 적용부위에 대고 석션 건을 통해 읍압을 형성하였다. 석션컵이 적용 부위에 부 착이 되면 참여자에게 능동적인 움직임을 하도록 하여 통 증과 가동범위에서 유의한 효과를 확인하였다[34, 35]. 다 만, 위의 두 선생연구에서는 압력에 대한 정확한 수치를 알 수 없었으며 또한, 근막 이완을 위해서는 전체 근육에 적용한 본 실험이 더욱 효과가 있을 것으로 생각된다. 추 후에 이 두 가지 방법의 비교 연구가 필요할 것으로 생각 된다.

목회전 범위의 군간 차이가 발생한 이유는 근막감압치 료로 인한 근막이완요법이 엘라스틴 섬유의 신장, 근막의 결절 지점에서 발생할 수 있는 교차결합의 제거와 기질의 점도가 고체에서 겔 상태로 바뀌는 변화로 인해 히알루론 산의 산물이 증가하고 근막조직의 미끄러짐이 증가하며, 근육과 건의 구성요소인 근방추세포와 골지건기관, 중추, 자율 그리고 말초신경계의 상태를 회복시켜 이완을 증진 시킨 결과로 생각된다[36].

$\mathrm{MDT}$ 를 적용하여 통증의 변화를 본 연구는 다양하게 찾아볼 수 있다.그 중에서 Teut 등[37]은 110 명의 만성 비특이성 허리 통증환자에게 맥동성 건식 cupping을 적용 하여 유의한 통증 감소의 효과를 확인하였다. 또한, 외측 상과염 환자에게 근막 감압 치료와 기능적 마사지 및 편 심성 운동을 적용한 비교연구에서도 대조군보다 유의한 통증 감소의 효과를 확인할 수 있었다[38]. 따라서 $\mathrm{MDT}$ 를 적용한 실험군이 대조군에 비해 통증감소의 효과를 본 이유는 음압으로 인한 물리적인 영향으로 근막과 근육 사 이의 유착이 감소하고 이로 인해 이 둘 사이의 움직임이 개선되어 통증이 감소된 것으로 생각된다.

선행 연구에 의하면 MDT는 음압에 의해 당겨진 적용 부위에 미세 순환이 개선되고 피부와 근육의 혈류를 증가
시킨다고 하였다[18, 27]. 이는 곧 피부 온도의 변화를 일 으킬 것으로 예상하였으나 실험군과 대조군 모두 유의한 피부온도 변화가 나타났지만 $(\mathrm{p}<0.05)$, 두 군의 비교에서 는 유의한 변화가 나타나지 않았다. 이는 두 군 모두에게 처치중 발생한 물리적 마찰이 피부표면에 자극을 주게 되 면서 위등세모근 부위의 피부온도가 다소 상승한 것으로 생각된다.

반면, 본 연구의 제한점은 치료 기간이 짧고, 중재 즉 시 측정을 했기 때문에 목장애지수 등의 변화를 측정하기 어려웠다. 또한, 실험 대상자가 적고 대체로 젊은 성인을 대상으로 하였다. 추후 연구에서는 중재 기간을 늘리고, 대상자의 수와 연령대를 다양하게 하여 실험할 필요가 있 다고 생각한다.

\section{결론}

본 연구의 결과에 따라 이동하며 적용한 근막감압치료 는 만성목통증 환자의 통증과 회전 범위 개선을 위한 물 리치료적 중재 방법으로 임상에서 적극적으로 사용될 수 있을 것으로 생각한다.

\section{이해 충돌}

본 연구의 저자들은 연구, 저작권 및 출판과 관련하여 잠재적인 이해충돌이 없음을 선언합니다.

\section{참고문헌}

1. Lee H, Nicholson LL, Adams RD. Cervical range of motion associations with subclinical neck pain. Spine (Phila Pa 1976). 2004;29:33-40.

2. Barry $M$, Jenner JR. ABC of rheumatology. Pain in neck, shoulder, and arm. BMJ. 1995;310:183-6.

3. Bogduk N. Neck pain. Aust Fam Physician. 1984;13:26-30.

4. Kim HJ. A study about the pains and cure in piaying piano. Busan: Kyungsung University Graduate school; 2003.

5. Kim JM. Review : Myofascial pain syndrome in general practice. Korean Journal of Family Medicine. 2001;22:1315-20.

6. Choi MJ. The effect of using both Myofascial Release Technique and Foot Reflexology on Static Body Balance. Seoul: Graduate school of engineering Konkuk University; 2009.

7. Scott J. Molecules that keep you in shape. New 
Scientist. 1986;111:49-53.

8. Choi JY. Beauty Promotion Effects Using Myofascial Release Therapy. Busan: Kosin University; 2007.

9. Barnes JF, Smith G. The body is a self-correcting mechanism. Phys Ther Forum. 1987;27.

10. Kim JH. The Effects of Ischemic Compression and Active Release Technique on Trigger Point of Upper Trapezius in Patients with Chronic Neck Pain. Daejeon: Eulji University Graduate school; 2016.

11. Lee BY. Literature investigation regarding cupping therapy and analysis of current professional's cupping performance. Seongnam: Kyungwon University; 2008.

12. Lone AH, Ahmad T, Anwar M, Habib S, Sofi G, Imam H. Leech therapy - a holistic approach of treatment in unani (greeko-arab) medicine. Anc Sci Life. 2011;31:31-5.

13. Teut M, Kaiser S, Ortiz M, Roll S, Binting S, Willich SN, et al. Pulsatile dry cupping in patients with osteoarthritis of the knee - a randomized controlled exploratory trial. BMC Complement Altern Med. 2012;12:184.

14. Ahmadi A, Schwebel DC, Rezaei M. The efficacy of wet-cupping in the treatment of tension and migraine headache. Am J Chin Med. 2008;36:37-44.

15. Cramer H, Lauche R, Hohmann C, Choi KE, Rampp T, Musial F, et al. Randomized controlled trial of pulsating cupping (pneumatic pulsation therapy) for chronic neck pain. Forsch Komplementmed. 2011;18:327-34.

16. Farhadi K, Schwebel DC, Saeb M, Choubsaz M, Mohammadi R, Ahmadi A. The effectiveness of wet-cupping for nonspecific low back pain in Iran: a randomized controlled trial. Complement Ther Med. 2009;17:9-15.

17. Stephens SL, Selkow NM, Hoffman NL. Dry Cupping Therapy for Improving Nonspecific Neck Pain and Subcutaneous Hemodynamics. J Athl Train. 2020;55:682-90.

18. Aeeni Z, Afsahi A, Rezvan H. An investigation of the effect of wet cupping on hematology parameters in mice (BALB/C). Research in Medicine. 2013;37: 145-50.

19. Ezzati K, Ravarian B, Saberi A, Salari A, Reyhanian Z, Khakpour M, et al. Prevalence of
Cervical Myofascial Pain Syndrome and its Correlation with the Severity of Pain and Disability in Patients with Chronic Non-specific Neck Pain. Arch Bone Jt Surg. 2021;9:230-4.

20. Bijur PE, Silver W, Gallagher EJ. Reliability of the visual analog scale for measurement of acute pain Acad Emerg Med. 2001;8:1153-7.

21. Kim DD. The Effects of Manipulation and Mobilization on NDI and CROM in Young Adults with Mild Neck Disability. Korean journal of orthopedic manual therapy. 2010;16:53-60.

22. Song KJ, Choi BW, Choi BR, Seo GB. Cross-cultural adaptation and validation of the Korean version of the neck disability index. Spine (Phila $\mathrm{Pa}$ 1976). 2010;35:E1045-9.

23. Lee C-Y, Song H-Y, Lee J-M, Chang M-Y. Usefulness of Smart Phone Application to Measure Cervical Range of Motion. The Journal of Korean Society of Community Based Occupational Therapy. 2017;7:17-24.

24. McKenzie R, May S. The Cervical Spine \& Thoracic Spine: Mechanical Diagnosis \& Therapy. ORTHOPAEDIC DIVISION REVIEW. 2007;-:38.

25. Castellote-Caballero Y, Valenza MC, Puentedura EJ, Fernandez-de-Las-Penas C, Alburquerque-Sendin F. Immediate Effects of Neurodynamic Sliding versus Muscle Stretching on Hamstring Flexibility in Subjects with Short Hamstring Syndrome. J Sports Med (Hindawi Publ Corp). 2014;2014:127471.

26. Portillo-Soto A, Eberman LE, Demchak TJ, Peebles C. Comparison of blood flow changes with soft tissue mobilization and massage therapy. J Altern Complement Med. 2014;20:932-6.

27. Tham LM, Lee HP, Lu C. Cupping: from a biomechanical perspective. J Biomech. 2006;39:2183-93.

28. Al-Bedah AMN, Elsubai IS, Qureshi NA, Aboushanab TS, Ali GIM, El-Olemy AT, et al. The medical perspective of cupping therapy: Effects and mechanisms of action. $\mathrm{J}$ Tradit Complement Med. 2019;9:90-7.

29. Cao H, Han M, Zhu X, Liu J. An overview of systematic reviews of clinical evidence for cupping therapy. Journal of Traditional Chinese Medical Sciences. 2015;2:3-10.

30. Schulte E. Acupuncture: where East meets West. RN. 1996;59:55-7.

31. Torebjork E. Nociceptor activation and pain. Philos 
Trans R Soc Lond B Biol Sci. 1985;308:227-34.

32. Michalsen A, Bock S, Ludtke R, Rampp T, Baecker M, Bachmann J, et al. Effects of traditional cupping therapy in patients with carpal tunnel syndrome: a randomized controlled trial. J Pain. 2009;10:601-8.

33. Kaptchuk TJ, Stason WB, Davis RB, Legedza AR, Schnyer RN, Kerr CE, et al. Sham device $v$ inert pill: randomised controlled trial of two placebo treatments. BMJ. 2006;332:391-7.

34. Warren AJ, LaCross Z, Volberding JL, O'Brien MS. Acute Outcomes of Myofascial Decompression (Cupping Therapy) Compared to Self-Myofascial Release on Hamstring Pathology after a Single Treatment. Int J Sports Phys Ther. 2020;15:579-92.

35. Smith K. Effect of Myofascial Decompression on Shoulder Range of Motion and Strength of Healthy Overhead Athletes. Ann Arbor: Oklahoma State University; 2015.

36. Kim KR, Shin HS, Lee SB, Hwang HS, Shin HJ. Effects of Negative Pressure Soft Tissue Therapy to Ankle Plantar Flexor on Muscle Tone, Muscle Stiffness, and Balance Ability in Patients with Stroke. J Intl Acad Phys Ther Res. 2018;9:1468-74.

37. Teut M, Ullmann A, Ortiz M, Rotter G, Binting S, Cree $\mathrm{M}$, et al. Pulsatile dry cupping in chronic low back pain - a randomized three-armed controlled clinical trial. BMC Complement Altern Med. 2018;18:115.

38. Heo JS. The effect of myofascial decompression therapy on pain, range of motion, muscle contraction characters and function in patient with lateral epicondylitis. Seoul: Sahmyook University; 2019. 